\title{
Pulmonary dirofilariasis in man : a new italian CASE. REVIEW OF THE EUROPEAN LITERATURE
}

\author{
PAMPIGLIONE S.*, DEL MASCHIO O.**, PAGAN V.*** and RIVASI F.****
}

\begin{abstract}
Summary :
In June 1991 a 62-year-old retired man, from Udine (northern Italy), was suddenly affected by dyspnoea. X-ray and CT control detected a coin lesion in the lung. In May 1992 this lesion was removed surgically. Histological examination revealed the presence of a nematode inside an arteriole which had provoked a small infarct in the pulmonary tissue. The parasite presented marked regressive phenomena that made an accurate morphological analysis impossible. However, in the light of certain details of the cuticle, and by analogy with four similar cases occurring in northern Italy, as well as 10 others (nine subcutaneous and one submucosall) reported in man from the same region (Venetia) over the last 15 years, the aetiologic agent was thought to be Dirofilaria (N.) repens. Over all 10 cases of human pulmonary dirofilariasis were reported in Europe : five in Italy, probably by D. (N.) repens, two in Germany, in patients coming from Corsica and two in Spain (only by serology), attributed to D. immitis. In addition one case was reported in U.S.A. in a man who previously visited Italy.
\end{abstract}

KEY WORDS : human dirofilariasis. lung. zoonosis. Europe. Dirofilaria sp. MOTS CLES : dirofilariose humaine. poumon. zoonose. Europe. Dirofilaria sp.

\section{INTRODUCTION}

$\mathrm{H}$ uman pulmonary dirofilariasis (HPD) is a helminthic zoonosis that came to light 33 years ago (Dashiell, 1961) and of which more then 160 cases have since been reported, mostly in the USA (Ciferri, 1982; Ro et al., 1989; Asimacopoulos et al., 1992) and Japan (Makiya et al., 1987; Makiya, 1990). It immediately attracted attention on account of its possibly being mistaken at Xray for lung cancer. Eight cases have so far been reported in Europe, two in Germany but relating to subjects from Corsica (Tornieporth et al., 1990; Wöckel et al., 1993), two in Spain (Cordero et al., 1990 ; Cordero et al., 1992) and four in Italy (Pampiglione et al., 1984; Fabbretti et al., 1990 ; Pampiglione et al., 1991a; Pampiglione and Fedeli, 1991; Pampiglione et al., 1994). Another case diagnosed in the USA (Darrow and Lack, 1981) can proba-

\footnotetext{
* Cattedra di Parassitologia Veterinaria, Università di Bologna, Italy. ** Servizio di Anatomia Patologica, Ospedale di Mestre, Italy. **** Servizio di Chirurgia Toracica, Ospedale di Mestre, Italy.

**** Dipartimento di Scienze Morfologiche e Medico Legali, Università di Modena, Italy.
}

Résumé : DirofILARIOSE PULMONAIRE HUMAINE : Un NOUVEAU CAS ITALIEN. REVUE DE LA LITTÉRATURE EUROPÉENNE

En juin 1991 un homme âgé de 62 ans, retraité, résidant en Vénétie (ltalie du Nord) est frappé brutalement par une crise de dyspnée. Sur la radio des poumons on observe un nodule du type "coin lesion", qui en mai 1992 est enlevé chirurgicalement. L'examen histologique du nodule révèle la présence d'un nématode qui a thrombosé une artériole en provoquant un petit infarctus. Le nématode présente des phénomènes régressifs marqués qui en empêchent une analyse morphologique détaillée. Sur la base de certains aspects de la cuticule et en analogie avec quatre autres cas très semblables diagnostiqués dans l'ltalie du nord et 10 sous-cutanés ou sous-muqueux dans la même région dans les 75 dernières années, il parait probable qu'il s'agit de Dirofilaria (N.) repens. Au total en Europe on a diagnostiqué 10 cas de dirofilariose pulmonaire humaine, dont cinq en Italie, tous dus probablement à D. (N.) repens, deux en Allemagne, mais provenant de la Corse, attribués à D. immitis, deux en Espagne attibués aussi à D. immitis (diagnostic sérologique), et un aux États Unis sur un sujet qui avait passé des vacances d'été en Italie, dû probablement à D. (N.) repens.

bly be attributed to Italy, where the subject had been on holiday four months previously.

In the USA, Japan and Spain and in the cases of Corsican origin the aetiology of the zoonosis is attributed to Dirofilaria immitis, a cosmopolitan nematode that is a common canine parasite, lodging in the host's heart. In Italy, on the other hand, the zoonosis appears to be associated to D. (Nochtiella) repens (Railliet et Henry, 1911), another canine parasite but which lodges under the skin and is found only in the Old World.

In this paper we describe a new Italian case and review those previously reported in Europe in an attempt to gain insight into a syndrome whose aetiopathogenetic and epidemiological aspects are still little known.

\section{CASE REPORT}

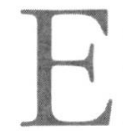
doardo A., 62 years, recently retired lorry-driver. Resident in Belluno (Venetia), spends summer at his daughter's in Vicenza (ibidem). 
Has never spent any time abroad. Light smoker, has frequent chest X-rays, as his father died of lung tuberculosis. Past history unremarkable, apart from the occasional bout of bronchitis in the last few years. In June 1991, while watching TV, he complained of a sudden dyspnoea but with no chest or abdominal pain. Admitted to Casualty, he was given an intramuscular injection (not specified) and improved rapidly. ECG revealed no sign of myocardial infarction; chest fluoroscopy was negative for lung lesions. However, a X-ray film performed 3 months later detected a solitary roundish mass in the left lung. X-rays and CT scan (fig. 1) conducted at intervals over the next few months revealed a nodule in the apical segment of the left lower lobe measuring $1.5 \times 2 \mathrm{~cm}$ with clearly defined margins and of varying density. A malignant "heteroplasia" was suspected. A trans-thoracic biopsy conducted under CT scan on 14/02/1992 revealed nothing more than a "carpet of erythrocytes and shreds of fibrous tissue". Bronchial aspiration, conducted a little later, also failed to detect any malignant cells. On 25/05/1992 the patient underwent left thoracotomy with marginal resection of the parenchyma containing the nodule. Intraoperative histological examination did not reveal any malignancy. The nodule was fixed in $10 \%$ buffered formalin and examined in histological sections stained with Haematoxylin and Eosin, Elastin, Masson-Goldner trichromic, PAS, Azan and Phosphotungstic Haematoxylin. Pertinent laboratory studies included a white-cell count ranged from 9,400 cells $/ \mathrm{ml}$ with $7.7 \%$ eosinophils on $15 / 02 / 1992$ to $12,100 \mathrm{cell} / \mathrm{ml}$ with $0.1 \%$ eosinophils on 16/05/1992. The other routine laboratory tests were normal.

\section{HISTOLOGICAL FINDINGS}

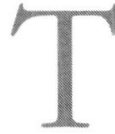
he fragment of lung parenchyma removed measuring, approximately, $2 \times 2.5 \mathrm{~cm}$ contained a firm, yellowish-white nodule $1.3 \mathrm{~cm}$ in diameter. Histological examination revealed a thick, fibrous outer shell consisting of fibroblasts, epithelioid cells, lymphocytes, occasional eosinophils and plasma cells with a core of largely necrotic material with infiltrated granulocytic mainly neutrophilic residues, haemosiderin and anthracotic deposits and evidence of tissue organisation. Residual alveolar spaces were full of fibrin-haematic and necrotic material, cell debris and acute and chronic inflammatory cells.

A few vascular lumina were, however, recognisable; they had necrotic walls and were obstructed with thrombotic material; in the broadest lumen there were long, irregular, tubular fragments ascribable to sections of a poorly-preserved nematode (figs 2, 3). In some sections an unusual phenomenon could be observed, namely, the concomitant breakdown of both a vascular and bronchiolar wall - the mucosa of the latter having foci of malpighian metaplasia (fig. 4) - with apparent penetration by the nematode into the same

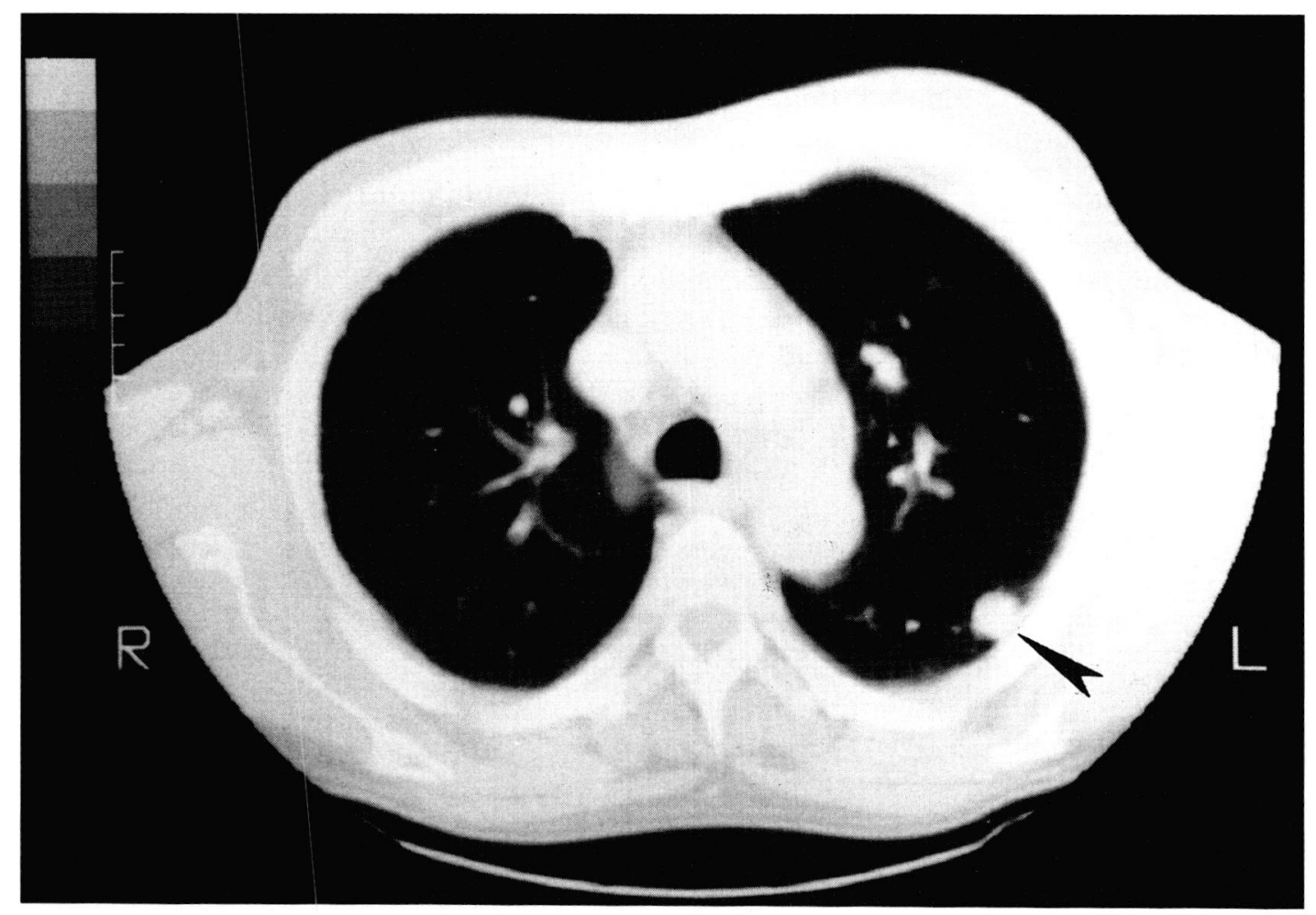

Fig. 1. - CT scan of the pulmonary nodule. 


\begin{tabular}{|c|c|c|c|c|c|c|c|}
\hline $\begin{array}{l}\text { Case } \\
n^{\circ}\end{array}$ & $\begin{array}{c}\text { Year of } \\
\text { publication }\end{array}$ & Authors & $\begin{array}{l}\text { Sex and age } \\
\text { of the subject } \\
\text { (in years) }\end{array}$ & Locality & Localization & $\begin{array}{l}\text { Symptoms and } \\
\text { signs - onset }\end{array}$ & $\begin{array}{l}\text { Aetiological } \\
\text { agent }\end{array}$ \\
\hline 1 & 1984 & $\begin{array}{l}\text { Pampiglione } \\
\text { et al. }\end{array}$ & F 57 & $\begin{array}{c}\text { Parma } \\
\text { (Emilia Romagna) }\end{array}$ & $\begin{array}{c}\text { Right upper lobe } \\
\text { subpleural }\end{array}$ & $\begin{array}{c}\text { Pains in the hemi- } \\
\text { thorax, } 38^{\circ} \text {, non } \\
\text { productive cough, } \\
\text { dispnoea. } \\
2 \text { months before }\end{array}$ & D. repens $\mathrm{M}$ \\
\hline 2 & 1990 & $\begin{array}{c}\text { Fabbretti et al. } \\
\text { (Pampiglione and } \\
\text { Fedeli, 1991) }\end{array}$ & M 58 & $\begin{array}{c}\text { Mesola } \\
\text { (Emilia Romagna) }\end{array}$ & $\begin{array}{c}\text { Left lower lobe } \\
\text { (base) subpleural }\end{array}$ & $\begin{array}{l}\text { Shifty pain in the } \\
\text { hemithorax, vomit, } \\
\text { asthenia. } \\
1 \text { year before }\end{array}$ & $\begin{array}{l}\text { D. repens } \mathrm{F} \\
\text { immature }\end{array}$ \\
\hline 3 & 1991 & $\begin{array}{l}\text { Pampiglione } \\
\text { et al. }\end{array}$ & M 66 & $\begin{array}{l}\text { S. Donà di Piave } \\
\text { (Venetia) }\end{array}$ & $\begin{array}{l}\text { Right upper lobe } \\
\text { subpleural }\end{array}$ & $\begin{array}{c}\text { Urticarial patches, } \\
\text { pruritus, paresthesia } \\
\text { on the back. } \\
3 \text { years before }\end{array}$ & $\begin{array}{l}\text { D. repens } \mathrm{M} \\
\text { immature }\end{array}$ \\
\hline 4 & 1993 & $\begin{array}{l}\text { Pampiglione } \\
\text { et al. }\end{array}$ & M 61 & $\begin{array}{l}\text { Alessandria } \\
\text { (Piedmont) }\end{array}$ & $\begin{array}{l}\text { Left upper lobe } \\
\text { (apex) subpleural }\end{array}$ & $\begin{array}{l}\text { Non productive } \\
\text { cough, pruritus, } \\
\text { intermittent pains } \\
\text { in the hemithorax. } \\
6 \text { months before }\end{array}$ & D. repens $\mathrm{F}$ ? \\
\hline 5 & 1993 & $\begin{array}{l}\text { Pampiglione } \\
\text { et al. }\end{array}$ & M 62 & $\begin{array}{l}\text { Vicenza } \\
\text { (Venetia) }\end{array}$ & $\begin{array}{c}\text { Left lower lobe } \\
\text { (apical segment) } \\
\text { subpleural }\end{array}$ & $\begin{array}{l}\text { Transient acute } \\
\text { dispnoea. } \\
8 \text { months before }\end{array}$ & $\begin{array}{l}\text { D. repens? } \\
\text { (in regressive } \\
\text { conditions) }\end{array}$ \\
\hline 6 & 1981 & Darrow and Lack & M 66 & $\begin{array}{c}\text { USA (but } 4 \text { months } \\
\text { before the patient } \\
\text { was in Italy) }\end{array}$ & $\begin{array}{l}\text { Right basal } \\
\text { lobe-subpleural }\end{array}$ & $\begin{array}{c}\text { Discovered only on } \\
\text { a routine chest } \\
\text { roentgenogram }\end{array}$ & $\begin{array}{l}\text { D. immitis? M } \\
\text { (but with cuticu- } \\
\text { lar indentation) }\end{array}$ \\
\hline
\end{tabular}

Table I. - Cases of human pulmonary dirofilariasis reported from Italy.

\begin{tabular}{|c|c|c|c|c|c|c|c|}
\hline $\begin{array}{c}\text { Case } \\
\mathrm{n}^{\circ}\end{array}$ & $\begin{array}{c}\text { Year of } \\
\text { publication }\end{array}$ & Authors & $\begin{array}{l}\text { Sex and age } \\
\text { of the subject } \\
\text { (in years) }\end{array}$ & Locality & Localization & $\begin{array}{l}\text { Symptoms and } \\
\text { signs - onset }\end{array}$ & Aetiological agent \\
\hline 1 & 1990 & Tornieporth et al. & F 39 & $\begin{array}{l}\text { Corsica } \\
\text { (France) }\end{array}$ & $\begin{array}{l}\text { Right lower lobe } \\
2 \text { nodules } \\
\text { subpleural }\end{array}$ & $\begin{array}{c}\text { Thoracic aches, } \\
\text { dispnoea, non pro- } \\
\text { ductive cough. } \\
3 \text { months before }\end{array}$ & D. immitis FF \\
\hline 2 & 1990 & Cordero et al. & M 27 & Spain & $\begin{array}{l}\text { Left upper lobe } \\
\text { (only Rx) } \\
\text { transient coin } \\
\text { lesion }\end{array}$ & $\begin{array}{l}\text { Thoracic aches, no } \\
\text { other symptoms. } \\
2 \text { months before }\end{array}$ & $\begin{array}{l}\text { D. immitis } \\
\text { only serology } \\
\text { (Elisa test) }\end{array}$ \\
\hline 3 & 1992 & Cordero et al. & M 72 & Spain & $\begin{array}{l}\text { Right basal lobe } \\
\text { (only } \mathrm{Rx} \text { ) } \\
\text { transient coin } \\
\text { lesion }\end{array}$ & $\begin{array}{l}\text { Productive cough, } \\
\text { low grade fever. }\end{array}$ & $\begin{array}{l}\text { D. immitis } \\
\text { only serology } \\
\text { (Elisa test) }\end{array}$ \\
\hline 4 & 1993 & Wöckel et al. & F 45 & $\begin{array}{l}\text { Corsica } \\
\text { (France) }\end{array}$ & $\begin{array}{l}\text { Right lower lobe } \\
2 \text { nodules } \\
\text { subpleural }\end{array}$ & $\begin{array}{l}\text { Thoracic aches, } \\
\text { mild non produc- } \\
\text { tive cough }\end{array}$ & $\begin{array}{l}\text { D. immitis } \\
\text { immature }\end{array}$ \\
\hline
\end{tabular}

Table II. - Cases of human pulmonary dirofilariasis reported from other countries of Europe 

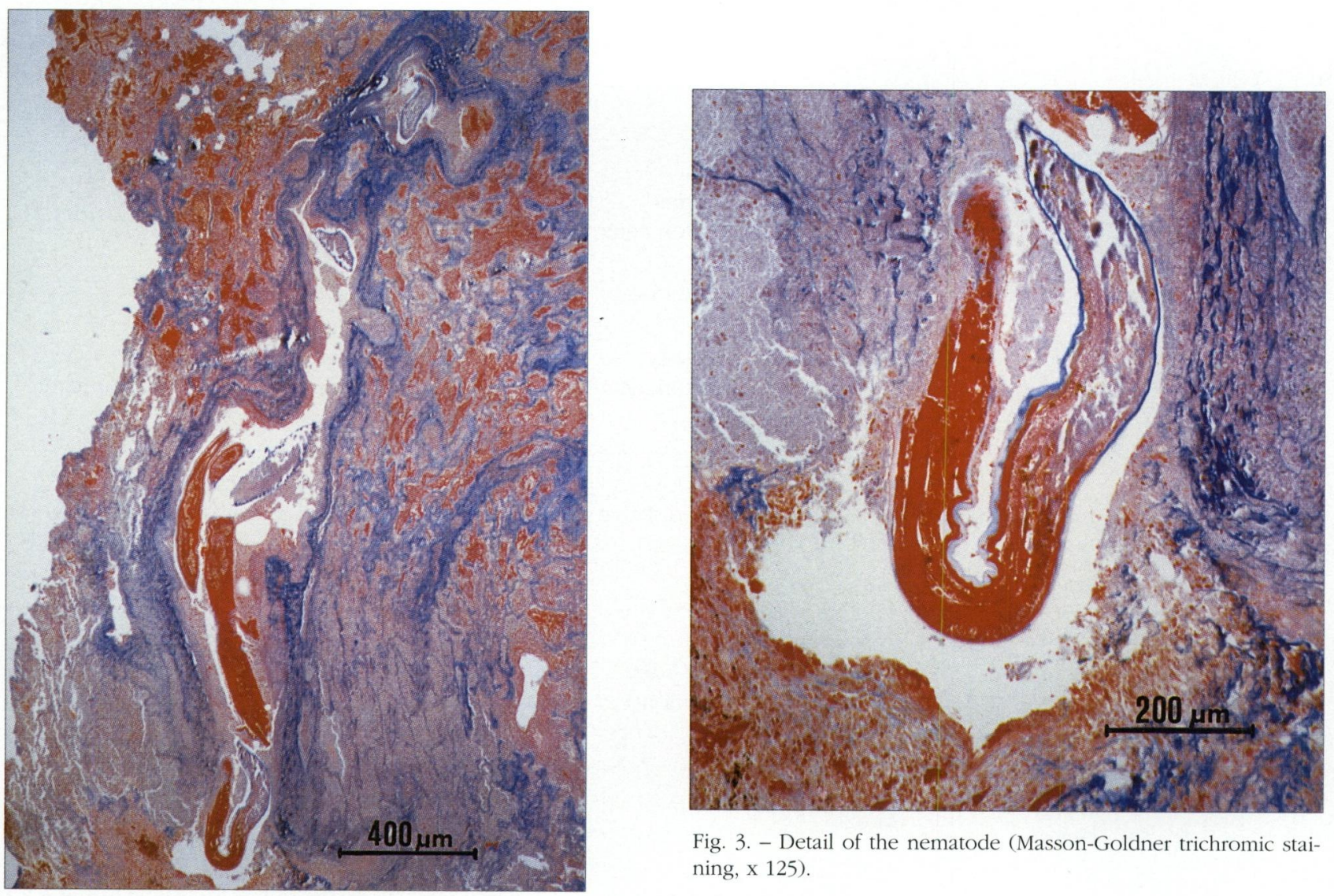

Fig. 3. - Detail of the nematode (Masson-Goldner trichromic staining, $x$ 125).

Fig. 2. - General view of the infarcted area with the blocked arteriole containing sections of the nematode (stained with Masson-Goldner trichromic staining, x 31).
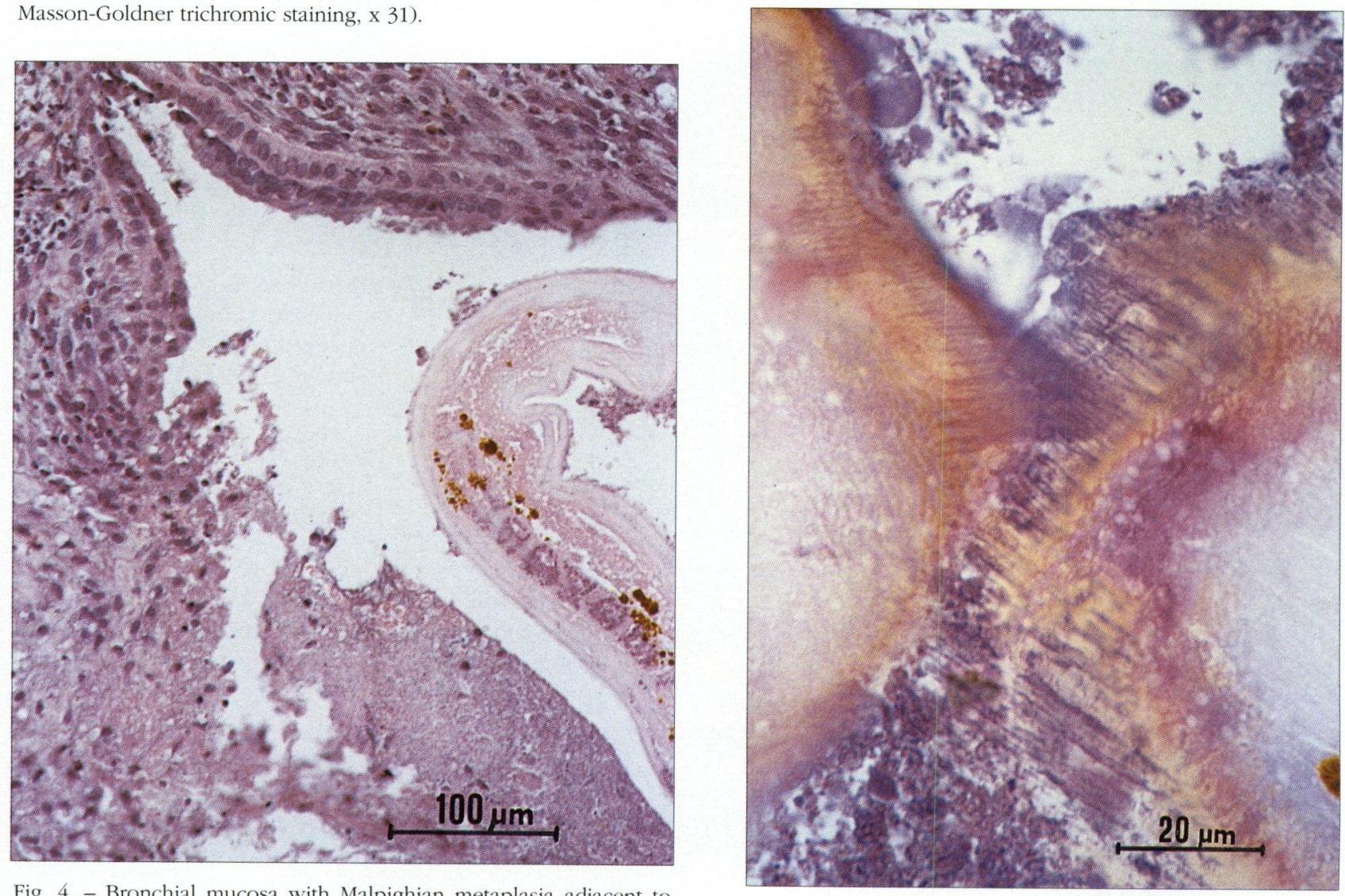

Fig. 4. - Bronchial mucosa with Malpighian metaplasia adjacent to the body of the nematode (haematoxylin/eosin, x 250).

Fig. 5. - Cuticular striae (haematoxylin/eosin, x 250). 
bronchiolar lumen. In the surrounding lung tissue an aspecific inflammatory reaction involving eosinophils and focal fibrosis was evident.

\section{PARASITOLOGICAL FINDINGS}

$\mathrm{T}$ he histological examination revealed some nematode sections (from three to eight per slide, depending on the level of the section), mostly in a state of advanced regression, surrounded by infarctual tissue inside a small arterial vessel. Some sections of the nematode were completely necrotic and had partially disintegrated; its shape could only be deduced from the remains of cuticula, which had worn very thin and had partly broken down. The sections of the parasite were mainly paralongitudinal or oblique, in a few cases paratransversal. The diameter of the nematode varied from 82 to $190 \mu \mathrm{m}$. The cuticula was often the only morphological feature still discernible; it was in poor condition, sometimes exfoliated, sometimes swollen. Where more intact, it varied in thickness between 7 and $13 \mu \mathrm{m}$ and appeared to consist of three layers. Along the edge of some not entirely necrosed sections longitudinal striae were present (fig. 5), 6-14 $\mu \mathrm{m}$ apart, corresponding to the cuticula; however, it was impossible to determine their thickness, nor could they be said to be actual ridges on the outer cuticular surface, given their regressive state. Other thinner striae about $1 \mu \mathrm{m}$ apart and transversal to the longitudinal axis of the nematode were also occasionally discernible. In a few sections, a thin hypoderma $(2-3 \mu \mathrm{m})$ and some muscular fibers were observed. Inside the nematode, only disparate necrotic tissue with no distinguishing features was present, although, in some sections, two longitudinal tubular structures, $22-30 \mu \mathrm{m}$ in diameter and presumably belonging to the genital and/or intestinal apparatus, were visible.

The morphological characteristics described above do not permit of any more than a very generic parasitological diagnosis of Dirofilaria sp. However, by analogy with the four Italian cases of HPD previously observed, and in view of the similarities both in the subject's clinical picture and in certain morphological features of the nematode (longitudinal striae in some sections on the surface of the cuticula), we can postulate an immature individual of $D$. (N.) repens.

\section{DISCUSSION}

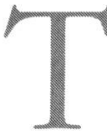

his case conforms to the well-defined picture of HPD. The clinical signs are modest pulmonary involvement together with a "coin lesion" X-ray picture, corresponding to a small infarctual nodule on the periphery of a lung. This nodule is caused by a thrombosis in the arteriole in which the nematode is lodging. The sudden bout of dyspnoea in June 1991, almost a year before the operation, is likely to have coincided with the occlusion of the arteriole; this is borne out by the appearance of the infarctual tissue, which was already partly structured at the time of the histological examination. The patient was probably bitten the previous year by an infected mosquito in Vicenza, where he is in the habit of spending the summer. Mosquitoes abound in summer in this region and $D$. (N.) repens has been reported here in dogs (Canestri-Trotti et al., 1986).

Furthermore, another case of HPD (Fabbretti et al., 1990) as well as 10 cases of subcutaneous or submucosa involvement (Pampiglione et al., 1991b), all of them due to $D$. (N.) repens, have been reported in the Venetia region. Comparing our findings with those previously reported in Italy (table I) and elsewhere in Europe (table II), we note that all 10 cases emerged in the last 13 years. This may be due not so much to a hypothetical spread of zoonosis as to greater importance being attached to solitary pulmonary nodules and to more frequent thoracic surgery thanks to an improvement in the facilities.

The patients vary in age between 27 and 66 years, the elderly being predominant, in line with the findings in the USA (Gershwin et al., 1974; Dayal and Neafie, 1975; Ciferri, 1982; Ro et al., 1989). Males are more commonly affected than females (seven out of 10 cases), again in line with American statistics. The parasite always lodges in the subpleural region, six in the right lung and four in the left. The nodules are single in eight cases; in the two cases from Corsica they are double. The diameter of the nodules does not exceed $3 \mathrm{~cm}$ and they appear in X-rays as "coin lesions". The symptomatology was acute, with sudden dyspnoea, in two cases, while in the remaining ones it was unobtrusive. In one case, discovered by chance during a routine radiological check-up, there were no symptoms whatsoever. Symptoms generally consisted of more or less localised chest pain and nonproductive cough; two patients ran a temperature, two experienced pruritus, one came out in a rash and one suffered vomiting. The time elapsing between the appearance of the first symptoms and removal of the nodule ranged from two months to three years.

Whereas in many subcutaneous cases in Italy, the nematode was well preserved or even alive, in cases of HPD the nematode was usually in a markedly regressive state. In three cases, it was male, in two female, while in five cases it was impossible to determine the sex. Correct diagnosis was possible in eight cases only after histological examination and disclo- 
sure of the parasite. In the Italian cases the parasite was identified as $D$. (N.) repens with stated reservations in the present case. Those of Corsican origin were thought to be D. immitis, while those reported in Spain and tentatively ascribed to D. immitis were diagnosed only radiologically and immunologically thus casting a slight doubt on the reliability of the diagnosis. In the eight cases subjected to histological examination the clinical diagnosis was consistently one of "malignant tumour", this justifying the importance that the American authors attach to the syndrome in the differential diagnosis of primary or metastatic lung cancer (Ro et al., 1989). In these cases surgery involved the removal of that portion of the lung containing the nodule. The histological finding was invariably of an infarction around a thrombotic arteriole in whose lumen the nematode was lodging surrounded by necrotic tissue. The infarction was always roundish, whereas the classical thromboembolic infarction is generally pyramidal in shape (Kochar, 1985).

In none of the American or European cases of HPD subjected to histological examination - and here we include our Italian cases - does it seem plausible to attribute infarction to mechanical obstruction of arterial flow by the nematode, for the vessel is never completely blocked by the parasite. The thrombus around the parasite appears to have formed gradually, and may be due either to a direct action on the intima of the vessel by heterogeneous substances released by the parasite, which was dead on arrival (Przyjemski, 1981; Bloch et al., 1990), or to a local antigen-antibody reaction or to both (Navarrete-Reyna and Noon, 1968; Neafie and Piggott, 1971). It is likely that, in time, the nematode would be broken down completely by inflammatory reaction and disappear; tissue-repair processes would then take place, as the findings of Cordero et al. (1990, 1992) relating to transient lung nodules, monitored radiologically and immunologically, would appear to demonstrate. In our case the formation of a passage between the pulmonary artery and the bronchus could be explained by the ropture of the necrotic vascular wall.

Analysis of the present case and of the others taken into account raises questions that are hard to answer for now. The five Italian cases all occurred in the same geographical locality, the Po Valley, and in a relatively restricted area. The aetiological agent appears to be D.(N.) repens and not D. immitis, although it might seem more logical to suspect the latter species, given its affinity for the vascular system, its abundance in dogs in the area, often greater than that of D. (N.) repens (Canestri-Trotti et al., 1986, 1988), and its potential pathogenicity for man, as amply demonstrated in other continents and in neighbouring
Corsica. Is it a question of different vectors ? Or of local strains with a differentiated propensity for thriving in man? Or of different immunological resistance in populations exposed for different periods of time to the parasite ? In order to find the answer to these questions, further entomological and immunological research is needed. Another question, already raised by some American authors (Beaver and Orihel, 1965) relates to the age of the subjects affected: why should the elderly appear to be more at risk ? One could suspect that it has to do with the lowering of the immune defences at that time of life. Ciferri, (1982), for example, noted that $11 \%$ of American cases of HPD involved subjects with impaired immunity to disease.

To conclude, autochthonous HPD can be said to exist in Europe, even if rarely reported. The syndrome is endemic to certain restricted areas of the Po Valley (northern Italy), to Corsica and perhaps to Spain. The presence of $D$. (N.) repens and/or D. immitis in dogs in vast areas of southern Europe leads one to suspect its occurrence in other regions. It is likely that undiagnosed cases escape the attention of the health authorities not only because there may be few or no symptoms but also because, if the microscopic examination is not meticulously performed, the nematode can escape detection and so remain unidentified (Ro et al., 1989).

\section{ACKNOWLEDGEMENTS}

This research received financial support from MURST (60\%).

\section{REFERENCES}

Asimacopoulos P.J., Kotras A. and Christie B. Pulmonary dirofilariasis. The largest single-hospital experience. Chest, 1992, 102, 851-854.

BeAver P.C. and Orihel T.C. Human infection with filariae of animals in the United States. American Journal of Tropical Medicine and Hygiene, 1965, 14, 1010-1029.

Bloch T., Glynn T. and Hinshaw M. Human pulmonary dirofilariasis. Indiana Medicine, 1990, 83, 24-27.

Canestri-Trotti G., Governatori M., Rivasi F., Tampieri A. and TARTONi P.L. Indagine sulla dirofilariosi canina in provincia di Modena. Modello epidemiologico statistico previsionale. Tecnica Sanitaria, 1988, 21, 283-297.

Canestri-Trotti G., Pampiglione S. and Visconti S. Ricerche sulla diffusione delle filariasi canine in alcune provincie della pianura padana. Annali Istituto Superiore di Sanità, 1986, 22,449-452.

CIFERRI F. Human pulmonary dirofilariasis in the United States : a critical review. American Journal of Tropical Medicine and Hygiene, 1982, 31, 302-308. 
Cordero M., Munoz M.R., Muro A. and Simon F. Transient solitary pulmonary nodule caused by Dirofilaria immitis. European Respiratory Journal, 1990, 3, 1070-1071.

Cordero M., Muro A., Simon F., Tapia J.I. and Espinoza E. Are transient pulmonary solitary nodules a common event in human dirofilariosis? Clinical Investigator, 1992, $70,437-440$.

DARROW J.C. and LACK E.E. Solitary lung nodule due by Dirofilaria immitis (dog "heartworm"). Journal of Surgical Oncology, 1981, 16, 219-224.

Dashiell G.F. A case of dirofilariasis involving the lung. American Journal of Tropical Medicine and Hygiene, 1961, 10, 37-38.

DAYAL Y. and NEAFIE R.C. Human pulmonary dirofilariasis : a case report and review of the literature. American Review of Respiratory Diseases, 1975, 112, 437-443.

Fabbretti G., Fedeli F., Alessi A., Boaron M., Salpietro V. and Brisigotti M. Human pulmonary dirofilariasis : report of a new European case. Histology and Histopathology, 1990, 5, 311-313.

Gershwin L.J., Gershwin M.E. and Kritzman J. Human pulmonary dirofilariasis. Chest, 1974, 66, 92-96.

KOCHAR A.S. Human pulmonary dirofilariasis. Report of three cases and brief review of the literature. American Journal of Clinical Pathology, 1985, 84, 19-23.

MaKIYA K. Dirofilariasis a parasitic disease possible acquired in the quotidian life environment. Medico, 1990, 21, 1417, (in Japanese).

Makiya K., Tsukamoto M. and Kagei N. Fifty-six cases of human dirofilariasis reported from Japan - a compiled table. Journal of the University of Occupational and Environmental Health, 1987, 9, 233-242. (in japanese)

Navarrete-Reyna A. and NoOn G. Pulmonary dirofilariasis manifested as a coin lesion. Archives of Pathology, 1968, 85, 266-271.

NeAfie R.C. and Piggott J. Human pulmonary dirofilariasis. Archives of Pathology, 1971, 92, 342-349.

Pampiglione S., Bosi F., Maconi A.G., Meriggi F., Remotti G. and SCaglia M. Pulmonary dirofilasiasis : clinical and parasitologic findings of a new human case. Giornale Italiano Malattie del Torace, 1994, 48, 1-4.

Pampiglione S., Candiani G., Del Maschio O. and Pagan V. Dirofilariasi polmonare nell'uomo : un terzo caso in Italia. Pathologica, 1991a, 83, 21-27.

Pampiglione S., Canestri-Trotti G. and Rivasi F. La dirofilariose humaine en Italie. Annales de Parasitologie Humaine et Comparée, 1991b, 66, 195-203.

Pampiglione $\mathrm{S}$. and Fedeli F. Dirofilariasi polmonare umana : aspetti parassitologici del secondo caso segnalato in Italia. Parassitologia, 1991, 33, 153-157.

Pampiglione S., Rivasi F. and Canestri-Trotti G. Human Pulmonary dirofilariasis in Italy. The Lancet, 1984, February 11, 333.

Przyjemski C. J. Dirofilaria immitis lung nodules. Journal of the American Medical Association, 1981, 245, 30-31.

Ro J.Y., Tsakalakis P.J., White V.A., Luna M.A., Chang-Tung
E.G., Green L., Cribbett L. and Alaya A.G. Pulmonary dirofilariasis : the great imitator of primary or metastatic lung tumor. Human Pathology, 1989, 20, 69-76.

Tornieporth N., Brandis A., Vogel B. and Disko R. Autochthone pulmonale Dirofilariose in Europe. Deutsche Medizinische Wochenschrift, 1990, 115, 15-19.

Wockel W., Eckert J Loscher T.H., Haussinger K. und Morresi A. Autochtone europäische lungen-Dirofilariose. Pneumologie, 1993, 47, 227-231.

Accepté le 8 juillet 1994 